\title{
地域施設整備過程の最適経路の性質 \\ OPTIMAL TRAJECTORY OF CONSTRUCTION PROCESS \\ OF REGIONAL FACILITY
}

\author{
青木義 次*, 納 富大輔** \\ Yoshitsugu AOKI and Daisuke NOUDOMI
}

\begin{abstract}
In the planning process of regional facilities, there are many interest groups who have the different opinions respectively. In common sense, it seems that the optimal construction process is determined by their opinions.

In this paper, a basic model of construction process of regional facility is formulated. Using the theory of Maximum Principle by Pontryagin, we show that the optimal construction process is independent on the opinions of interest groups. Furthermore, we show the condition on the possibility of construction process.
\end{abstract}

\section{keywords: Optimal trajectory, regional facilities, construction process, Pontryagin's Maximum Principle}

最適経路, 地域施設, 整備過程, ポントリヤーギンの最大值原理

\section{1.はじめに}

公立病院, 保育所, 図書館などいわゆる地域施設の整備にあたっ ては, 総合的・長期的視点にたって計画されるべきことは言うまで もない。また, 地域施設の大半を計画し, 建設し, サービスする地 方公共団体にとっては，篇しい予算制約の中で大きな負担となって おり，合理的かつ効率的な施設整備が求められている。

しかし, 現行財政制度上, 単年度予算を前提とする中で, 長期的 展望にたった計画の実施には多くの困難が存在している(凶)。また, 施設整備が求められる地域であればあるほど，いわゆる新住民の増 加も顕著であることが多く，そのニーズも固定的に把握することが 難しい。加えて，たとえ一施設の計画であっても，地方公共団体内 の関連部局をはじめとして, 多くの個人, 団体がその計画過程に参 与し，かつ立場や価値意識を異にしていることを考えると，総合的 整備ということは具体的な計画の場では難かしい(文2,3)。

本研究は，上記の視点にたち，異なる立場や価値意識を持った複 数の計画参画者や組織のもとでの地域施設整備の長期的に望ましい 過程とは何かについて理論的に考察することを試みる。

この研究課題に関して,線形モデルという特殊なケースにおいて, 最適な整備過程は各計画参画者の価値意識に依存していないという 一般通念とは逆な結果を, 青木(文) が報告している。その当時は, こ の一見奇妙な結果は, 線形モデルという特殊なケースだけのことと 考えられていた。しかし, 本論文では, この計画参画者の価値意識 の非依存性は，一般化したケースで成立していることを報告する。

\section{2. 地域施設の整備過程}

以下では, 地方自治体における計画策定過程の調査研究(文5,6)等を もとに，地域施設整備過程をお扔まかに記述し，施設整備過程の基 本モデルを定式化しておく。

\section{2-1 単年度型予算方式と長期的展望}

地域施設の整備にあたってその必要費用の負担形態は，それぞれ の施設, 計画団体(地方白治体等)によって異なり, 単に自己団体の 中だけにとどまらず，国からの補助金等に依存することもあるが， いずれにしても，その年度 $t$ において確保しうる財源 $\bar{z}(t)$ のうち から当該施設への支出 $y(t)$ を行ない施設整備に充当することにかわ らない。一方施設の整備水準 $x(t)$ は,この支出の結果,一般的には 上昇すると思われる。この事実は, 支出による整備水準増加量を表 す関数 $g(y(t))$ を用いて以下のように記述することができる。

$$
\begin{aligned}
& y(t) \leq \bar{z}(t) \\
& \dot{x}(t)=g(y(t)) \\
& g \geq 0, \frac{\partial g}{\partial y}>0
\end{aligned}
$$

また，整備のための支出 $y(t)$ は，明らかに負になりえない值であ る。また，施設を維持してゆくなどの制約から支出額の下限が決ま り，これを $\underline{z}$ と記せば，以下の条件が付加されることとなる注1。

$$
0 \leq \underline{z} \leq y(t)
$$

* 東京工業大学大学院理工学研究科建築学専攻 教授・工博 ** 東京工業大学大学院理工学研究科建築学専攻 大学院生
Prof., Dept. of Architecture, Tokyo Institute of Technology, Dr. Eng. Graduate Student, Dept. of Architecture, Tokyo Institute of Technology 
以下では，略して $\bar{z} ， \underline{z}$ を単に予算上限，下限と呼ぶこともあ る。さらに $y(t)$ を建設量, $x(t)$ を施設量と呼ぶことも, $y, x$ と 略記することもある。

計画団体における各年度の予算・支出を上述したが長期的展望に たった整備目標年次 $t^{*}$ ，及び達成す心゙き施設の整備水準 $x^{*}$ は, 別 のプロセスで決定されることが多い。つまり，長期計画，長期構想 等の名称で別途策定されるのが実態である(文7)。以下では, 整備目標 年次 $t^{*}$, 現状の施設整備水準 $x_{0}(=x(0))$, 達成目標整備水準 $x^{*}$ は すでに決定されているものとして分析をすすめ，各年度の建設量 $y(t)$ をどのようにすれば, 長期的に望ましいかを検討し，その結果 から望ましい目標年次, 達成目標整備水準の值を吟味する。

\section{2-2 計画過程における多様な価值意識}

地域施設の整備過程に関わる個人，団体は異なる立場や価值意識 を持っているのが通常であり，それぞれの立場や価值意識に基づき 整備計画過程へ参画し影響を与えている。彼らの洒值意識を整備計 画に対してなされる要請（要望）という視点から整理すると，以下 の様なものがある。

（1）サービス水準(地域施設の効用, 地域施設から住民が得る利便）を 上昇させたい。

（2）地域施設への住民からの需要に応じてほしい。

(3) 達成目標整備水準を一日も早く達成したい。

これらの他にも種々様々な要請があり，とくに計画団体の特殊 性, 地域, 施設の固有の性質にかかわるものもある。実際の整備 過程は，このような多様な価值意識が同時に存在しており，それ 故に，総合的計画への期待があるとも言えよう。

ここでは, 上記(1)〜 (3)の要請を以下のように定式化しておきた W。

(1) サービス水準最大化

地域施設のサービス水準の向上を第一に望み，これを要望する立 場の価值意識を「サービス水準最大化」の価值意識と呼び, 以下, こ の価值意識を定式化する。

地域施設が整備されているからといって住民に対するサービスが 良いと結論することには問題がある。施設が完備していても，施設 へ至る交通機関の有無, 施設の運営形態等によって, 住民へのサー ビスの水準は変化すると考えられる。また，同一の施設であっても 住民の施設に対する評価は年を追うごとに厳しくなり相対的にサー ビス水準は低下しているようにとられることもある。この様な状況 を考えるとサービス水準最大化の価值意識は，数学的に以下のよう に記述できよう。すなわち

$$
s(t)=f_{s}(x(t), t)
$$

で表わされるサービス水準 $s(t)$ を最大化することであり,関数 $f_{s}$ は一般に以下の条件を満たしている注2。

$$
\begin{aligned}
& \frac{\partial f_{s}}{\partial x}>0 \\
& \frac{\partial f_{s}}{\partial t} \leq 0
\end{aligned}
$$

(2) 需要対応化
前述のサービス水準最大化の考え方は，常に施設水準の上昇を期 待し，とどまるところがない。これに対し，住民のニーズに応じた 適切な水準まで整備されれば良いという考え方々あり，これを「需 要対応化」の価值意識と呼ぶ。この場合，適切な水準に対する現状 での不足感 $n(t)$ を最小化したいということもできる。一方, 適切な 水準ということは，本来ならば長期計画によって達成目標整備水準 $x^{*}$ となっていなければならない。従って, 不足感 $n(t)$ は, 以下の 様に記述できる。

$$
\begin{aligned}
& n(t)=f_{n}(u(t), t) \\
& u(t)=x^{*}-x(t)
\end{aligned}
$$

また, 不足量 $u(t)$ が大きい程不足感は大きいと考えられるので

$$
\frac{\partial f_{n}}{\partial u}>0
$$

と表わせる。上記 (4-1)式で不足感 $n(t)$ が時間の関数になっている のは, 時間とともに, 地区人口の変動等があり,一定の施設量であっ ても, 不足感が変動することを考慮したものである。施設整備がと くに問題となるのが人口増加地域であることを想定して以下のよう に仮定しておく。

$$
\frac{\partial f_{n}}{\partial t} \geq 0
$$

これらの条件のもとで需要に応じた整備をすべきであるとする価值 感は，不足感 $n(t)$ を最小化することと定式化できる。

(3) 早期達成化

一日も早く目標整備水準に達成したいという考え方を「早期達成 化」の価值意識と呼び, 達成されていない不満 $p(t)$ を最小化する ことと考えると,これは不足量 $u(t)$ を用いて以下の様に表わすこと ができる注 3 。

$$
\begin{aligned}
& p(t)=f_{p}(u(t)) \\
& \frac{\partial f_{p}}{\partial u}>0
\end{aligned}
$$

以上で, 先の価值意識を数学的に定式化したが，この他の様々な 価值意識を除外しておくことでは，非現実的である。そこで，以後 の理論展開においては, その他の価値意識を表現するものとして, 非顕在的価値意識を数学的に定式化しておく。

(4) 非顕在的価值感

文字通り顕在的に記述できないような多くの価値意識を表現する ため, ある変量 $v(t)$ を考え,この值が大きいほど望ましいとする上 述の (1) 〜 (3) 以外の価值意識が存在していると想定する。これは経 済学では, (1)〜 (3) 以外の価值感をもつ人々の社会的効用関数に対 応するものである。ところでこの変量の性質についての知識が全く ない現状では，次のような仮定を導入せざるを得ない。すなわち， 変量 $v(t)$ は施設量 $x(t)$, 建設量 $y(t)$ に完全に独立であるとする。

\section{2-3 総合的計画}

前項で整理された 4 種の価值意識のいずれにウェイトをおくべきか 
は,まさに洒值感の問題であり,工学的に決定できる範囲の外にある と考えるべきであろう。従って, 本研究では, 地域施設整備過程の良 さ悪さを計る尺度 $J$ は, 上述のサービス水準 $s(t)$, 不足感 $n(t)$, 非達成不满 $p(t)$ 及び非顕在的価値感を表わす変量 $v(t)$ の関数で表 わされるということのみを基本前提とする。

ところで,整備過程が時刻 0 から達成年次 $t^{*}$ までを考えているの で整備過程の良悪を表わす尺度は,一般的に以下の様に表現できる。

$$
J=\int_{0}^{t^{*}} f_{T}(s(t), n(t), p(t), v(t)) d t
$$

すなわち,この尺度 $J$ を最大化することが地域施設の整備過程の最 適化である。

ところで, サービス水準 $s(t)$ 及び非顕在的価値感を表わす変量 $v(t)$ は最大化すべき量であり, 需要に対する不足感 $n(t)$ 及び早期 達成に対する不満 $p(t)$ は最小化すべき量として各価值感で前提と されていた点と, 総合的尺度 $J$ が各価值感を包括しかつ最大化すべ き量であるとすることから，次の条件が成立している。

$$
\frac{\partial f_{T}}{\partial s}>0, \frac{\partial f_{T}}{\partial n}<0, \frac{\partial f_{T}}{\partial p}<0, \frac{\partial f_{T}}{\partial \nu}>0
$$

さらに尺度 $J$ は (3-1), (4-1)，(4-2)，(5-1)式を(6)式に代入するこ とによって次の様に表わすこともできる。

$$
J=\int_{0}^{* *} \hat{f}_{T}(x(t), t) d t
$$

\section{3. 地域施設整備過程の最適化}

\section{3-1 最大值原理による基礎モデルの最適化}

前節で記述された地域施設の整備過程では，どんな場合でも成立 していると思われる性質だけを定式化したものであって，定式化さ れた関係式の中に表われる関数の形も特定化していない。この意味 で, (1)式から (8)式で与えられた関係式は，より基本的なものであ り，これらを地域施設整備過程の基礎モデルと呼ぶ。より具体的情 報を引き出すために, 青木(文4)では, この基礎モデル中の関数形を線 形であるという特殊ケースでの検討をした。本論文では, 線形モデ ルで得られたとほほ同等な結論が一般的に基礎モデルで成立するこ とを報告する。

基礎モデルでは, (8)式で与えられる尺度 $J$ の值を最大化すること であり，この場合，ポントリヤーギンによる最大值原理(文8,9)を利用 しうる。

(8)式を最大化するような各年度の地域施設整備への支出 $\hat{y}(t)$ の 時刻 0 から目標年次 $t^{*}$ までの変化を最適な地域施設整備あるいは, 最適整備と呼ぶ。このとき最大值原理によれば，最適整備 $\hat{y}(t)$ は次 の条件を満足する必要がある。つまり，

$$
\begin{aligned}
& H(\phi, x, y)=\hat{f}_{T}+\phi \cdot g(y(t)) \\
& \frac{\partial \phi}{\partial t}=-\frac{\partial H}{\partial x}
\end{aligned}
$$

で定義されるハミルトニアン $H$ が最適整備 $\hat{y}(t)$ で最大となってい ることが必要である。すなわち

$$
H(\phi, x(\hat{y}), \hat{y})=\operatorname{Max}_{y} H(\phi, x, y)
$$

この関係式及び前節での関係式から, 最適な地域施設整備 $\hat{y}(t)$ の
決定手続きを示す次の補題 1 を得る。

補題 1 : 最適な地域施設整備 $\hat{y}(t)$ は, 以下に示す $\theta$ の値の正負に より，それぞれ予算制約の上限 $\bar{z}$ ，下限 $\underline{z}$ になる。

$$
\theta=-\int \frac{\partial \hat{f}_{T}}{\partial x} d t+c
$$

ただし，c は次の条件を満たす。

$$
\int_{A} g(\bar{z}(t)) d t+\int_{B} g(\underline{z}(t)) d t=x^{*}-x_{0}
$$

ここに $A$ は $\theta$ が正となる時，B は負となる時を表わす 時刻の集合である。

証明）(8)式より， $\hat{f}_{T}$ は $y$ の関数でないので

$$
\frac{\partial \hat{f}_{T}}{\partial y}=0
$$

となり，この条件を考えて $(9)$ 式を $y$ で偏微分すれば

$$
\frac{\partial H}{\partial y}=\left[-\int \frac{\partial \hat{f}_{T}}{\partial x} d t+c\right] \cdot \frac{\partial g}{\partial y}=\theta \frac{\partial g}{\partial y}
$$

したがって $H$ を最大化するような $y$ を決定することは， (2-2) 式の条件を考えれば(12)式で与えられる $\boldsymbol{\theta}$ の正負に 応じて, $y$ の上限又は下限をとるようにすることとなる。 この補題中の (13) 式は, 最適整備の結果, 現状 $x_{0}$ から達成目標 整備水準 $x^{*}$ に至ることを保証するためのものである。

さらに(12)式で与えられる $\theta$ の正負の変化する時刻は 1 回だけ であることを示す次の補題を得ることができる。

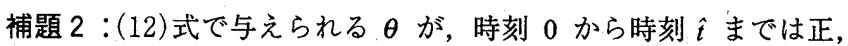
時刻 $\hat{t}$ から時刻 $t^{*}$ までは負とする，時刻 $\hat{t}$ (ただし $0 \leq \hat{t} \leq t^{*}$ )がただひとつ存在する。

証明）（12）式の被積分関数は,

$$
\begin{aligned}
\frac{\partial}{\partial x} \hat{f}_{T}(x(t), t) & =\frac{\partial}{\partial x} f_{T}(s(t), n(t), p(t), v(t)) \\
& =\frac{\partial f_{T}}{\partial s} \frac{\partial s}{\partial x}+\frac{\partial f_{T}}{\partial n} \frac{\partial n}{\partial x}+\frac{\partial f_{T}}{\partial p} \frac{\partial p}{\partial x}+\frac{\partial f_{T}}{\partial v} \frac{\partial v}{\partial x}
\end{aligned}
$$

であり,(7)の第1式および $(3-2)$ 式より，

$$
\frac{\partial f_{T}}{\partial s} \frac{\partial s}{\partial x}>0
$$

(7)の第 2 式および(4-2) (4-3)式より,

$$
\frac{\partial f_{T}}{\partial n} \frac{\partial n}{\partial x}>0
$$

(7)の第 3 式および (5-2) (4-3)式より,

$$
\frac{\partial f_{T}}{\partial p} \frac{\partial p}{\partial x}>0
$$

変量 $v$ が変量 $x$ に独立であるという前提より,

$$
\frac{\partial v}{\partial x}=0
$$

これら(17)の結果から，

$$
\frac{\partial}{\partial x} \hat{f}_{T}(x(t), t)>0
$$

したがって, 正の関数を時間について積分した值に負符号 
を付したものである $\theta$ は時間に関して単調減少関数とな る。このことから， $\theta$ の符号の変化は正から負に高々 1 回 しか起こらないことが分かる。

最適整備の方法を示す次の定理が, 上記のふたつの補題から直ち に得られる。

定理 $1: 0 \leq \hat{t} \leq t^{*}$ を満足する時刻 $\hat{t}$ が唯一存在し, 最適な地域施 設整備 $\hat{y}(t)$ は，時間範囲 $0 \leq t<\hat{t}$ では予算制約の上限 $\bar{z}$ に，時間範囲 $\hat{t} \leq t \leq t$ *では予算制約の下限 $\underline{z}$ になる。

\section{3-2 最適整備過程の性質と計画可能性}

上記の定理から，最適整備過程は，ある時刻までは予算制約の上 限をとり,それ以降, 整備完了までは下限をとることが結論され，具 体的な施設整備の望ましい方法が与えられた。

しかし，この定理は，具体的な最適整備の方法を与えるだけでな く,より重要な意味をもっている。それは, 次の事実を含意してい るからである。

命題 $1:$ 切りかえ時刻 $\hat{t} か ゙$, 各計画参画者の価值意識や要請と独 立に決まり, 結局, 最適整備過程はこれら参画者の価値意 識の如何によらず同一のものとなる。

命題 2 ：実現可能な最適整備計画が存在するためには, 次の条件が 満足されていなければならない。

$$
\int_{0}^{t^{*}} g(\underline{z}(t)) d t \leq x^{*}-x_{0} \leq \int_{0}^{t^{*}} g(\bar{z}(t)) d t
$$

この事実を確認するために，まず，図1のように整備過程を図示 しておくことにする。横軸が時刻で，縦軸に各時刻での施設量と現 在の施設量との差をとる。図中の太線が最適整備過程で, 曲線 $\mathrm{B}_{1}$ は，最初から最後まで予算の下限値を用いて整備していった場合を 表し, 曲線 $\mathrm{B}_{2}$ は, 最初から最後まで予算の上限值を用いて整備し ていった場合を表している。

最適整備過程では, 当然, 時刻 0 で施設量は $x_{0}$ であり, 時刻 $t$ で施設量は達成すべき施設の整備水準 $x^{*}$ になっていなければなら ない( $b$ 点で示される)。また、定理 1 より，切り替え時刻までは予 算上限で,切り替え時刻以降は予算下限で整備することになるので, 図のように予算下限の過程でなおかつ $b$ 点を通過する曲線が, 切り 替え時刻以降の最適整備過程と一致する。したがって， $b$ 点を通過 するこの曲線と, 図の原点を通過する予算上限の曲線 $\mathrm{B}_{2}$ との交点

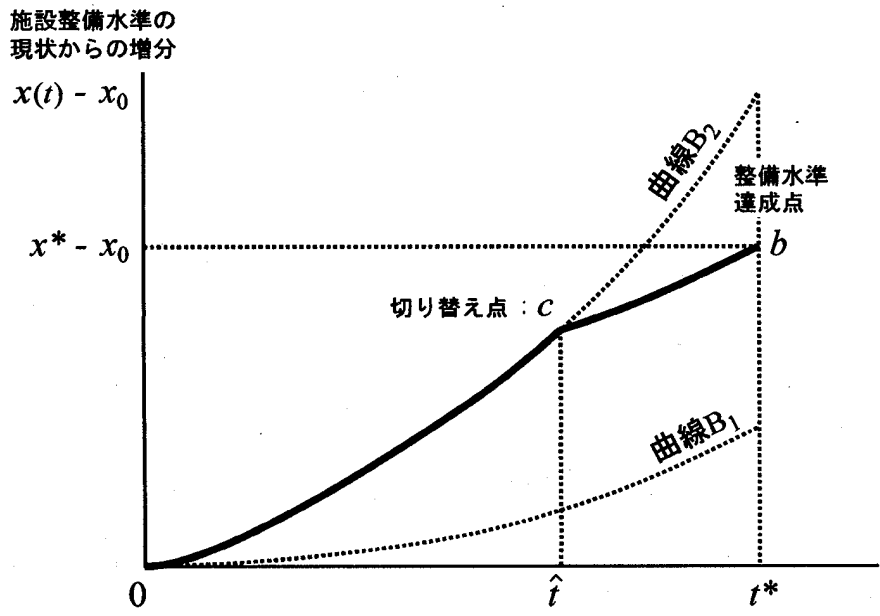

図 1 計画可能性と最適経路 $c$ での時刻が切り替え時刻に他ならない。曲線 $\mathrm{B}_{2}$ も曲線 $c b$ も, 予算制約 $\bar{z} ， \underline{z}$ と (2-1)の関数だけによって決まる。つまり, 参画 者の価值意識に依存することなく切り替え点が決まり, 命題 1 が正 しいことが分かる。

命題 2 も図から明らかであるが, 次のように考えると分かり易い。 まず, (2-2)及び(1)式の条件によれば,

$$
0 \leq g(\underline{z}(t)) \leq g(y(t)) \leq g(\bar{z}(t))
$$

であるので

$$
0 \leq \int_{0}^{t} g(\underline{z}(t)) d t \leq \int_{0}^{t} g(y(t)) d t \leq \int_{0}^{t} g(\bar{z}(t)) d t
$$

となる。又, 整備完了時点 $t^{*}$ で整備水準が目標值 $x^{*}$ になること及 び，現状，すなわち時刻 0 で整備水準が $x_{0}$ であることから，微分 方程式 (2-1)の解は

$$
\begin{aligned}
& x(t)=\int_{0}^{t} g(y(t)) d t+x_{0} \\
& x\left(t^{*}\right)=x^{*}
\end{aligned}
$$

を満たさなければならない。したがって,この両式から(21)の条件 は(19)式のように書きかえることができる。

命題 2 の (19)式は，与えられた条件の範囲で目標の整備水準が達 成可能か否かを判別する条件式であり,この意味で命題 2 は, 施設 整備計画の実現可能性の最低必要条件を示すものと言える。

\section{4. 結論}

地域施設整備過程における単年度型予算を前提とした長期的最適 化の問題を, 多様な価値感の存在する状況下で考察し, 次の成果を 得た。

（1）最大値原理により，最適な施設整備の達成する方法を示す定理 1 を得た。

(2) 定理 1 の系として, 最適な施設整備過程は価値意識に依存する ことなく一意に決定されることを示した。

(3)達成目標整備水準, 目標年次が所与の時に，現実的に実現でき るかどうかを示す条件式(19)を求めた。

注 1）予算下限は時間によって変化すると考えても以下の議論は同じになる。 注 2)ただし，(3-3）は以下の定理の導出には用いない。

注3) 整備目標年次に達成目標水準になっていることを本論では想定している が、早期達成の面からそれ以前に達成していることもある。

参考文献

1. 谷口沉邦・青木義次: 新学園建設に関する基䃈的諸条件の調査研究, 日本地 域開発センター, 1976

2. 谷口沉邦・青木義次:公共施設における計画過程の構造分析, 日本建筑学会 論文報告集第 238 号, pp. 107-116, 1975

3. 谷口沉邦・青木義次: 公共施設における計画過程の情報関連分析, 日本建築 学会論文報告集第 239 号, pp. 107-113,1976

4. 青木義次: 地域施設整備過程の最適化とその意味について, 第 2 回地域施設 計画研究シンポジウム発表論文集「地域施設計画研究 2$\rfloor, p p .111$ 116,1984

5. 安田八十五・青木義次他: 都道府県における公共政策策定のための基䃈研究, 地方自治情報センター，1975

6. 石見利勝・青木義次他:地方経済情報システムに関する調查研究，地方自治 情報センター，1980

7. 青木義次: 計面の構造と手法, 建設省建留研究所, 建築研究報告第 80 号, 1977

8. ポントリヤーギン他 (関根訳): 最適過程の数学的理論, 総合図書, 1967

9. ボルチャンスキー (阪本訳): 最適制御の数学的方法, 総合図書, 1968 